\title{
Wellbeing at the Edges of Ownership
}

\section{Susan J. Smith}

Department of Geography and Girton College, Cambridge University, UK

\section{Melek Cigdem}

Melbourne Institute of Applied Economic and Social Research, University of Melbourne, Australia; Centre for Urban Research, RMIT University, Australia

\section{Rachel Ong}

Bankwest Curtin Economics Centre, Curtin Business School, Curtin University, Australia; Centre for Urban Research, RMIT University, Australia

\section{Gavin Wood}

Centre for Urban Research, RMIT University, Australia; OTB - Research for the Built Environment, Faculty of Architecture and the Built Environment, Delft University of Technology, The Netherlands

\section{Environment and Planning A,}

Accepted 16 December 2016 for publication in 2017

\begin{abstract}
The test of a well-functioning housing system is the wellbeing of its occupants. It may therefore seem encouraging that in jurisdictions dominated by mortgage-backed home ownership owner-occupiers traditionally report better physical and mental health than renters. During the 2000s, however, in an era of financial crisis, wellbeing at the edges of ownership came under strain. Using data from two national panel surveys the survey of Household, Income and Labour Dynamics in Australia, and the British Household Panel Survey (with its successor, Understanding Society) - we track the wellbeing of households who sustained one or more spells of home ownership in the decade to 2010. We estimate log-log regression models of mental wellbeing for each country, documenting (with an appropriate range of controls) the effects of both tenure transitions (between ownership and renting) and some associated financial transactions (anchored on mortgage debt). We find: a wellbeing premium associated with outright ownership and a debt-effect among mortgagors; a lower wellbeing among those who drop out of owner-occupation, with partial recovery where exit is enduring; and for leavers especially, a wellbeing cost to equity borrowing. Crossnational differences have an institutional explanation, but similarities relating to the character and regulation of mortgage markets are more striking.
\end{abstract}

Key words- Wellbeing, housing, owner-occupation, mortgage debt, panel surveys 


\section{INTRODUCTION}

The costs and benefits of systems for the provision of goods and services, and of the policy interventions that shape them, are increasingly measured against the yardstick of wellbeing (DEFRA 2005). Housing is a prime example (Clapham 2010). It may therefore seem encouraging that in jurisdictions dominated by mortgage-backed home ownership, owner-occupiers traditionally report better physical and mental health than renters (Easterlow et al. 2000; Filakti and Fox 1995). There are myriad explanations for this: systematic differences between tenure sectors in the character and quality of the housing stock and in the health hazards built into it (Evans et al., 2000; Lloyd et al. 2008); health selectivity, or discrimination, in access to and exit from owneroccupation (Smith 1990; Smith and Easterlow 2005); the positive health effects of housing wealth (Fichera and Gathergood 2013); and factors other than tenure per se that are differentially associated with the health profiles of home owners and renters (Baker et al. 2013; Dalstra et al. 2006; Macintyre et al. 1997; Macintyre et al. 2003; Mason et al, 2013; Nicholls et al 1998), particularly place and neighbourhood (Lekkas et al. 2016; Pemberton and Humphries 2016).

This paper offers a complementary view, rooted in a literature which embraces the diversity of health and wellbeing within, as well as between, tenure sectors, yet which explains that diversity with reference to the operation of the housing system itself. Cairney and Boyle (2004), for example, argued some time ago for the importance, when considering the relationship between home ownership and psychological distress, of distinguishing between outright owners and mortgagors. Likewise, Nettleton and Burrows $(1998,2000)$ found persuasive evidence linking psycho-social stress among mortgagors to unsustainable debt, mortgage arrears and the risk of 
repossession. There are strong a priori reasons, therefore, for recognizing a health gradient within owner occupation, from the ontological security of outright ownership to the psychological distress of foreclosure (Rohe and Lindblad, 2013).

Views of this gradient have been coloured, of course, by the advent and impact of a global financial crisis (GFC) that was rooted in the characteristics of tenure-divided, ownership-centred housing economies (Smith 2013). This has naturally turned attention to the health effects of economic instability generally (Stuckler et al. 2009; Karanikolos et al. 2013; De Vogli 2014), and of credit and debt in particular (Bridges and Disney 2010; Keese and Schmitz 2014; Lenton and Mosely 2008; Sweet et al. 2013). However the economic shocks of the 2000s have also fuelled speculation around two central features of the housing economy. First, the health effects of mortgage borrowings, which now dominate households debt portfolios (Burgard et al. 2012; Mason et al. 2013). Second, the impacts and health selectivity of housing transitions out of ownership (Libman et al. 2012; Pevalin 2009; McLaughlin et al. 2011), especially those linked to an epidemic of foreclosures in the USA (Downing 2016; Ross and Squires 2011).

A great deal of recent research has, unsurprisingly, focused on the USA, where the drive to mortgage securitization originated, together with the credit crisis it inspired. To enlarge the debate, we use panel survey data to profile the UK and Australia whose ownership-centred housing systems differ from their better-documented US counterparts in two important respects: firmer financial regulation; and more complete mortgage markets. 
Firmer financial regulation protected UK and Australian households from the worst excesses of the US foreclosure crisis, mitigating the accumulation of arrears and the risk of repossession. While this did not entirely insulate home-buyers from the adverse effects of the credit crunch, forced transitions into renting, especially in the UK, were lower than in previous crises (Wood et al 2015). In the first of two modeling exercises reported below we find the wellbeing dimensions of these transitions to be correspondingly complex.

More complete mortgage markets initially allowed for some expansion at the edges of ownership (Scanlon et al. 2008), encouraging both an increase in the population of mortgagors and a growth in their borrowing. Crucially, however, $21^{\text {st }}$ century mortgage products introduced a distinctive style of financial flexibility to mortgagors, viz. equity borrowing. This is a method of mortgage equity withdrawal whereby, for little or no additional charge, and without moving home, mortgagors can (and did) add to their loans, releasing funds for both housing and non-housing expenditure (Smith and Searle 2008).

On the one hand, this in situ borrowing adds liquidity to households' accounts, enabling housing wealth and mortgage debt to feature in day-to-day budgeting decisions where it can buffer unanticipated falls in income and help meet acute spending needs (Benito 2007; Parkinson et al, 2009). On the other hand, because it also adds to debt, equity borrowing may contribute to financial stress, especially in an era of asset-based welfare (Ong et al. 2013; Wood et al, 2013). While the psychosocial ramifications of mortgage arrears bear further scrutiny, the implications for wellbeing of the early $21^{\text {st }}$ century borrowing 'bonanza' are largely untested (though 
see Searle et al. 2009). In the second modeling exercise reported in this paper, therefore, we document not only the effects of mortgage debt, but also, and independently, the impacts of equity borrowing.

Although this study is not offered as a comparative exercise sensu stricto, the panel surveys are structured to enable a cross-national perspective (just as their design and privacy agreements inhibit finer grained place- or neighborhood-based analyses). So while the discussion starts from the premise that there are some jurisdiction-specific attributes of the provision and regulation of housing finance in which the UK and Australia are similar to each other and somewhat distinct from the USA, the analysis is also sensitive to the possibility that even quite similar housing and mortgage markets may be mediated by institutional differences. Developing this theme, the aim in the remainder of the paper is to test the effects of both tenure transitions and financial transactions on wellbeing in Australia and the UK. We begin with an overview of data resources and an account of the modeling exercises. This is followed by a description and interpretation of results, and a short conclusion. 


\section{METHODOLOGY}

\section{Data Resources and Descriptives}

The data used in this paper are sourced from the British Household Panel Survey (BHPS) together with its successor (Understanding Society), and from the Household Income and Labour Dynamics in Australia (HILDA) Panel Survey. There is increasing use of such data to unpack the dynamics of unhealthy housing (Pevalin et al. 2008), to identify the housing underpinnings of life satisfaction (Zumbro 2014), and to explore the health effects of debt (Keese and Schmitz 2014). We add to this tradition. Although the BHPS dates from 1991, we match the surveys from the first wave of HILDA in 2001 and run the analysis to the end of the decade. In this period the British panel contained 10,000 households (19,000 individuals) and its Australian counterpart just under 8000 (7682) households (nearly 14,000 individuals).

Panel surveys interview the same people every year. Their longitudinal nature offers a unique opportunity to track changes in wellbeing through time, and match them with housing pathways, as well as with associated biographical disruptions and economic shocks. Similarities in the structure and data collection methods of the BHPS and HILDA facilitate cross-country comparison, as well as within country generalisations (though confidentiality agreements limit the use of individual records, or the tagging of data with locations). The surveys are rich in variables, tapping into a range of socio-economic characteristics, as well a panoply of subjective and quasi-subjective indicators of health and wellbeing, including validated self-assessed health questionnaires. The variables extracted for this paper have been carefully matched across datasets using consistent procedures to ensure comparability (see Wood, Parkinson et al. 2013 for details). 
We employ a sample design that includes all independent adults who report one or more spells of owner-occupation (each spanning one or more years) between 2000 and $2010,{ }^{1}$ commencing from the first wave in which an individual is observed as an owner. ${ }^{2}$ Table 1 summarises their housing trajectories across the decade. This shows that, once they attain owner occupation, most retain it: they are ongoing owners. A minority drops out (one in five in Australia; less than one in ten in the UK): around half of these remain in the rented sector (lasting leavers); the rest return to ownership before the end of the study period (churners). Churning is more common in Australia than in the UK, for reasons we have outlined before (Wood et al. 2015)

Table 1 Owner-occupier housing trajectories 2001-10

\begin{tabular}{|l|l|l|l|l|l|}
\hline & $\begin{array}{l}\text { At least one } \\
\text { ownership } \\
\text { spell }\end{array}$ & $\begin{array}{l}\text { Ongoing } \\
\text { owners }\end{array}$ & $\begin{array}{l}\text { Exited } \\
\text { ownership }\end{array}$ & $\begin{array}{l}\text { Lasting } \\
\text { leaver }\end{array}$ & Churner \\
\hline HILDA & 5894 & 4616 & 1278 & 508 & 770 \\
\hline Row \% & 100 & 78 & 22 & 9 & 13 \\
\hline BHPS/US & 5532 & 5061 & 471 & 277 & 194 \\
\hline Row \% & 100 & 91 & 9 & 5 & 4 \\
\hline
\end{tabular}

Source: Authors' calculations from the 2001-10 HILDA Survey, 2001-08 BHPS and US wave 2.

As well as tracking wellbeing across tenure transitions, we are interested in the financial transactions that prevent or precipitate this. Mortgage debt is the most obvious of these. In HILDA about a third of ongoing owners $(1,551)$ owned outright to 2010; fully two-thirds $(3,070)$, therefore, were mortgagors for at least some of their ownership years. In the UK, there is a similar split (1700 outright owners; 3361

\footnotetext{
${ }^{1}$ By 'independent' adults, we refer to individuals who are no longer dependent on their parents. Arguably individuals could be clustered into households, since it is generally combined resources that trigger housing decisions. However, longitudinal surveys track household formation and dissolution, and this is an important element of the current analysis. The individual with household characteristics tagged in each year is the more meaningful unit where the aim is to show how (or control for the extent to which) household dynamics impact on wellbeing (see Wood et al. 2012 for discussion of this attribution approach to measurement using panel data).

${ }^{2}$ Observations prior to this are excluded from the sample design; spells in ownership that were ongoing at the onset of the period of observation are left censored.
} 
mortgagors).

A particular feature of our analysis is that it captures the effects of equity borrowing. This was a common financial tactic among mortgagors in the early 2000 s, employed by nearly two-thirds (60\%) of ongoing owners in Australia and just over half $(52 \%)$ in the UK. Leavers and churners appear, at first glance, to be ten to twenty per cent (respectively) less active in this respect in both countries. However, this mainly reflects the fact that leavers and churners are owners for shorter stretches of time and have correspondingly less opportunity to engage in equity borrowing. In terms of frequency relative to their time as owner-occupiers, leavers in the UK, and both leavers and churners in Australia, are more active than ongoing owners as documented in Wood et al. (2013)

For the purposes of our modeling exercise we include, for each individual, one 'count' per variable per year (a person-year observation) from the first ownership episode. For instance, consider an individual who entered home ownership in 2003, but left in 2006 and remained in the rental sector until the end of the timeframe. We would include eight person-year observations for this individual, comprising observations from 2003 to $2010^{3}$. Three of those years would be rolled into one spell in ownership; five would constitute one subsequent spell of renting. The individual would be classified as a leaver since there is no return to ownership during the study period. The modeling exercise described later refers to each person-year as an 'episode', though it should be noted that wellbeing descriptives are, where appropriate, also presented by ownership 'spell'.

\footnotetext{
${ }^{3}$ We omit person-years with missing values on any of the variables used in the analysis.
} 
Typically, wellbeing is measured contemporaneously with (in the same year as) any time varying life event, including exit from home ownership. We construct the measures of wellbeing as follows. HILDA records the mental health component of the SF36, on a scale of 0 (least healthy) to 100 (most healthy); BHPS and US use the GHQ12 on a scale of 0 (least distressed) to 36 (most distressed). ${ }^{4}$ For heuristic purposes, we follow Searle (2008) by using the inverse of the GHQ12 scale in our analysis so that, in the case of both countries, higher scores on the mental health variable denote greater wellbeing. ${ }^{5}$

Descriptive statistics for key variables in the study are given in table 2. Remember, all variables are measured for each individual for each ownership year (and, for leavers and churners, also for each subsequent renting year). That is, each person-year in the study is tagged with the characteristics and attributes exhibited by a given person in that single year. Table 2a lists the means, medians and standard deviations for continuous variables; table $2 \mathrm{~b}$ lists the categorical variables (showing the percentage of person-years in which the indicated personal characteristic is present).

From these tables we see that the commonest age in either country is 52; the majority of person-years (over $70 \%$ in both countries) are spent in marriage, and without dependent children (60\% in Australia, $67 \%$ in the UK); and a much higher proportion of UK than Australian cycles are associated with long-term disability or illness (61\% compared with $24 \%$, though the measures are not directly comparable).

\footnotetext{
${ }^{4}$ For details on the derivation of the SF36 and GHQ12 scales, refer to Ware et al. (1993) and Goldberg et al. (1997) respectively.

${ }^{5}$ Tacitly, therefore, we assume that by inverting the mental health scale, we can derive a measure of mental wellbeing. This is not ideal, but is the best proxy in the dataset.
} 
Household incomes are equivalised, and mean incomes are marginally higher in the UK than Australia ${ }^{6}$. However, the higher standard deviation in Australian incomes is notable, and might account for the very high incidence of irregular savings cycles reported there. Fewer UK than Australian cycles are completed by those with university degrees, but the commonest employment status in both countries is either full-time or not in the labour force (primarily due to retirement). Part-time working occurs in almost $20 \%$ of person-years in both countries, but underemployed cycles, reported by part-time workers who want to work more hours, are much more common in Australia. Wellbeing is measured in different units in Australia and the UK, so it is not possible to say that levels are higher in one jurisdiction than in the other. It is, however, worth noting that wellbeing is less variable than household incomes in both countries. $^{7}$

Table 2: Descriptives overview

(a) Continuous variables

\begin{tabular}{|l|ll|ll|}
\hline \multirow{2}{*}{ Variable name } & Australia & & UK & \\
\cline { 2 - 5 } & $\begin{array}{l}\text { Mean } \\
\text { (median) }\end{array}$ & $\begin{array}{l}\text { Standard } \\
\text { deviation }\end{array}$ & $\begin{array}{l}\text { Mean } \\
\text { (median) }\end{array}$ & $\begin{array}{l}\text { Standard } \\
\text { deviation }\end{array}$ \\
\hline Wellbeing (Aus 0-100; UK 0-36) & $\begin{array}{l}76.4 \\
(80.0)\end{array}$ & 16.2 & $\begin{array}{l}24.9 \\
(26.0)\end{array}$ & 5.2 \\
Age (years) & $\begin{array}{l}51.8 \\
(51.0)\end{array}$ & 14.1 & $\begin{array}{l}52.2 \\
(51.0)\end{array}$ & 14.9 \\
$\begin{array}{l}\text { Real equivalised household gross } \\
\text { income ('000s) }\end{array}$ & $\begin{array}{l}\$ 63.8 \\
(\$ 53.6)\end{array}$ & $\$ 48.0$ & $\begin{array}{l}£ 29.4 \\
(£ 25.4)\end{array}$ & $£ 18.9$ \\
\hline
\end{tabular}

\section{(b) Discrete variables}

\section{Australia}

UK

\footnotetext{
${ }^{6}$ Converted to pounds, mean (median) household equivalised income in Australia is $£ 27,924$ ( 22,890 ); the standard deviation is $£ 22,307$. Exchange rates for conversion are measured annually for every year across the data range.

${ }^{7}$ Wellbeing measures have the same coefficient of variation $(0.21)$ in both countries. Income has a coefficient of variation equal to 0.64 in Britain, but is even higher at 0.75 in Australia.
} 


\begin{tabular}{|l|c|c|}
\cline { 2 - 3 } Variable name & \% person-years & \% person-years \\
\hline Female & 45.2 & 41.3 \\
Married & 71.7 & 73.3 \\
De facto & 7.7 & 8.0 \\
Separated & 3.0 & 1.6 \\
Divorced & 6.2 & 5.1 \\
Widowed & 6.0 & 7.2 \\
Single never married & 5.5 & 4.9 \\
No dependent children & 59.9 & 66.8 \\
One dependent child & 12.2 & 13.5 \\
Two dependent children & 18.2 & 14.8 \\
Three dependent children & 9.7 & 4.9 \\
Long-term disability/illness & 24.3 & 60.7 \\
University qualification & 25.0 & 17.8 \\
Other post-secondary & 33.1 & 64.6 \\
qualification & 41.9 & 49.9 \\
Secondary qualification & 43.3 & 39.7 \\
Employed full-time & 19.8 & 19.4 \\
Employed part-time & 1.2 & 1.1 \\
Unemployed & 35.6 & 39.7 \\
Not in labour force & 37.3 & 1.5 \\
Underemployed & 28.5 & 25.9 \\
Volunteer & 44.5 & 51.4 \\
Active community group & 23.7 & 53.0 \\
participation & 52.5 & 9.2 \\
Does not save & 23.8 & 37.7 \\
Saves irregularly & & \\
Saves regularly & & \\
\hline
\end{tabular}

Source: See table 1

Note: There are 46,195 and 42,587 person-year observations in the Australian and UK samples respectively.

\section{Analytical strategy}

The analysis takes a sample of owner-occupiers and, using the distinctive qualities of panel surveys, models the drivers of wellbeing as ownership careers evolve. We specify two models. The first quantifies the implications for wellbeing of tenure transitions out of, and occasionally back into, owner-occupation. The second adds the effects of debt.

The tenure transitions model tracks tenure shifts across the study period to show how 
the mental health profiles of those who exit compare to those of a control group of ongoing owners. The sample design and model specification yield estimates of whether those leaving ownership are predisposed to lower wellbeing levels (reflecting, perhaps, the adverse life events that trigger eventual exit), but separately detects possible changes in wellbeing following moves into rental housing. Among those who exit at all, a distinction is drawn between individuals who regain ownership over the study timeframe $(2001-2010)$ and those who do not.

We adopt a difference-in-difference model specification and initially use a random effects estimator that is defined by:

$W_{e l l}=\alpha_{0}+\alpha_{1} L_{i}+\alpha_{2} L_{i} *$ post $_{i t}+\alpha_{3} C_{i}+\alpha_{4} C_{i} *$ post $_{i t}+a_{i}+u_{i t}$

where $i$ and $t$ subscript individuals and time period respectively, and $W e l l_{i t}$ is our measure of mental wellbeing for individual $i$ at time $t$, as defined above. Timeinvariant indicator variables distinguish between ongoing owners, lasting leavers $\left(L_{i}\right)$ and churners $\left(C_{i}\right)$. These variables enter regression models separately, with ongoing owners the omitted category. The included ownership pathway categories are also interacted with a variable (post $t_{i t}$ ) identifying whether wave $t$ belongs to an episode when leaver $i$ (or churner $i$ ) is renting ${ }^{8}$.

A vector of controls is added that include socioeconomic and demographic variables previously recognised (and commonly thought of) as determinants of wellbeing ${ }^{9}$. This is common practice in similar studies (previously cited). In equation (1) controls are

\footnotetext{
${ }^{8}$ More formally each variable is defined as follows;

- $\quad \mathrm{L}_{\mathrm{i}}$ equals one if the person loses ownership and has not returned to owner-occupation by 2010 , zero otherwise;

- $\quad \mathrm{C}_{\mathrm{i}}$ equals one if the person loses ownership but returns to owner-occupation at least once by 2010, zero otherwise

- $\quad$ Post $_{i t}$ equals 1 in wave $t$ if individual $i$ is renting in that wave, zero otherwise.

${ }^{9}$ The controls are also measured at time $t$.
} 
added for income (as well as the capacity to save from income), demographics (including sex, marital status, age, presence of children, health and disability), human capital (educational qualifications, employment) and participation in community organizations. We identify any variation in wellbeing across the decade by adding calendar year dummies which will control for any 'GFC effect'.

The income variable warrants further discussion, since it is defined to include net imputed rents (the income deemed to have been received from net housing equity ${ }^{10}$ ) as well as income from earnings, interest, dividends and other income flowing from financial assets and property investments. By adopting this comprehensive income measure, we treat wealth accumulated in owner-occupation (net of mortgage debt) in the same way as other assets in households' wealth portfolios ${ }^{11}$. The model therefore controls for the asset and debt position of individuals in the sample ${ }^{12}$.

The parameters $a_{i}$ and $u_{i t}$, are an unobservable fixed effect and a random disturbance term respectively, and they make up a composite error term $\vartheta_{i t}=a_{i}+u_{i t}$. The individual-specific component of the composite error $\left(a_{i}\right)$ recognizes that each person contributes multiple observations to the panel, and there are likely to be unmeasured fixed personal traits that could affect each person's mental wellbeing (e.g. innate pessimism). These will cause serial correlation in the composite error. Random effects estimation (RE), however, assumes that the individual specific component of the error

\footnotetext{
${ }^{10}$ Commonly interpreted to be the value of the housing services a home owner is deemed to have supplied to themselves by virtue of investing in and owning housing, minus the expenses incurred in supplying these housing services.

${ }^{11}$ Net imputed rents are calculated as $5 \%$ of housing equity, the difference between owners' assessment' of home value and outstanding mortgage debt, as reported in HILDA.

${ }^{12}$ The income variable has been log transformed. A similar functional form is employed by Oswald and Powdthavee (2008) who model the effect that disability has on mental health.
} 
$\left(a_{i}\right)$ is uncorrelated with measured variables included in the model. This assumption is hard to warrant or dispel but is partially addressed by a sample design that seeks to eliminate variation in unobserved fixed personal traits that are correlated with tenure, and therefore with included variables. Our sample thus comprises persons that begin as owners who are then followed over time, rather than one which begins with owners and renters and then compares wellbeing profiles after adjustment for controls.

To illustrate, suppose we had adopted a sample design containing all renters and owners at the start of the observation period but the former were inherently pessimistic and the latter inherently optimistic - traits that are unmeasured in the data set. This difference in unobservable fixed personal traits is likely correlated with earnings and hence income (See Mueller and Plug (2006), Nyhus and Pons ( 2005); and Bowles, Gintis and Osborne (2001)), which is one of the measured variables in the model. Our aim, however, is to avoid this. This is achieved by restricting the sample design to those with a spell of ownership in the study period - a strategy by which these systematic differences (between owners and renters) in unmeasured variables are purged from the model.

The RE estimator is a Generalized Least Squares solution, that has the advantage of addressing serially correlated composite errors due to the presence of $a_{i}$, without losing potentially valuable information on time-invariant factors affecting differences in the level of mental health that would otherwise be lost with a fixed effects (FE) regression model. This is particularly important in our case because some of the key variables in the tenure transition model (e.g. whether a person has exited home ownership over the study time frame), are time-invariant. 
Our estimates of alpha coefficients in equation (1) measure differences in wellbeing levels across different ownership career categories. The estimated coefficient $\widehat{\alpha_{1}}$ indicates whether leavers are prone to lower levels of mental health (as compared to ongoing owners), regardless of their tenure status at the time. It therefore measures whether those moving out of home ownership are predisposed to lower levels of wellbeing, and would therefore have inferior levels of mental health even had they not left home ownership. The estimated coefficient $\widehat{\alpha_{2}}$ captures the impact of enduring exit on post-departure levels of mental wellbeing. If positive, it indicates that the transition into rental housing is associated with a rebound in levels of wellbeing. A negative finding suggests that moves out of owner-occupied housing further lower levels of wellbeing. The estimated coefficients $\widehat{\alpha_{3}}$ and $\widehat{\alpha_{4}}$ have a similar interpretation.

In addition to tenure transitions, we are interested in the wellbeing effects of financial transactions, and this is explored in a second random effects modeling exercise. Mortgage debt is, for most households, a requirement for accessing owneroccupation; outright ownership comes later. Equity borrowing is, similarly, a financial transaction that is only available to owner-occupiers, but that became widespread in the early 2000s. The nature of panel survey data makes it possible to compare the wellbeing of ongoing owners who do, and who do not, have mortgages, and who have and have not engaged in equity borrowing, with the wellbeing of leavers and churners who did, or did not, make use of these financial tools during their ownership spells. The wellbeing implications of these behaviours are estimated in a second model that, while controlling for mortgagor status and housing equity (via the income measure), 
adds interactions between housing pathway indicators and a measure that captures in situ equity borrowing during the course of an ownership spell ${ }^{13}$.

\footnotetext{
${ }^{13} \mathrm{An}$ in situ equity borrowing dummy is created that takes the value 1 if a person makes an in situ
} addition to their mortgage during an ownership spell, zero otherwise. 


\section{RESULTS}

\section{A tenure transitions model}

Table 3 reports random effect estimates from the Australian and UK data sets. It indicates that a number of well-established factors significantly and independently lift wellbeing among Australian and UK households. These include gender (women generally report better wellbeing than men), marital status (partnering has a protective effect) and age (older people do better, all else equal). Higher incomes also have a protective effect ${ }^{14}$, as does employment, and community participation. Financial stressors, indexed here by inability to save, have a predictably negative impact on wellbeing. The calendar year estimates (not listed) reveal evidence of a 'GFC' effect on wellbeing: they show, in both countries, a negative turn in the later years (beginning in 2008 in the UK, and evidenced in 2010 in Australia).

Controlling for all these and some other known and measurable influences, the model indicates that leavers in both countries exhibit significantly and substantially lower levels of wellbeing than ongoing owners ${ }^{15}$. In the extent to which it depresses wellbeing, this 'exit effect' is larger than the effect of most other variables in the models. Only separation is more damaging, together with unemployment in the UK. The exit effect can be detected among those at risk, even prior to them leaving, and it operates independently of the effect on wellbeing of other measurable factors that

\footnotetext{
${ }^{14}$ In an earlier version of the model the income variable (which excluded home owners' net imputed rents), had a weaker effect. In the Australian model estimated by RE the income coefficient is only 0.38 (for the UK, 0.13 ) when net imputed rents are omitted from the income definition. We are grateful to an anonymous referee for prompting this variable redefinition.

${ }^{15}$ Length of tenure in home ownership could also exert an influence on wellbeing pre- and postdeparture. However, the variable has been omitted from the model as the left-censored nature of the data does not permit measurement of actual tenure for those observed to be home owners at the start of the data timeframe (2001).
} 
might precipitate departure (e.g. separation, unemployment or the onset of financial crisis).

We can further judge the magnitude of the exit effect by comparing it to the effects of other adverse events and circumstances known to be the cause of sharply lower mental health (Smith et al 2005). Estimates in table 3 suggest that in both countries wellbeing is depressed for leavers (compared to ongoing owners) substantially more than it is depressed across the sample by factors more commonly associated with low mood, such as long term disability and illness. For churners, who cycle out of, and then back into homeownership, the wellbeing gap with ongoing owners is not as pronounced as for leavers, though it is still statistically significant (at 5\% in Australia, $1 \%$ in the UK).

Table 3: Tenure transitions model, random effects ${ }^{1}$

\begin{tabular}{|l|l|l|l|l|}
\hline Variable name $^{2}$ & \multicolumn{2}{|c|}{ Australia } & \multicolumn{2}{c|}{ UK } \\
\hline Tenure status & Coefficients & \multicolumn{1}{|c|}{ SE } & \multicolumn{1}{|c|}{ Coefficients } & SE \\
\hline Leaver & $-3.75^{* * *}$ & 0.60 & $-0.91^{* * *}$ & 0.24 \\
Churner & $-0.99^{* *}$ & 0.49 & $-0.85^{* * *}$ & 0.28 \\
Leaver x left home ownership [L x post] & $1.23^{* * *}$ & 0.44 & $0.58^{* * *}$ & 0.21 \\
Churner x left home ownership [C x post] & -0.26 & 0.35 & 0.17 & 0.27 \\
\hline Income and savings habit & & & & \\
\hline Log real equivalised household gross income & $0.62^{* * *}$ & 0.15 & $0.27^{* * *}$ & 0.07 \\
('000s) & & & & \\
Do not save & $-2.46^{* * *}$ & 0.21 & $-0.25^{* * *}$ & 0.06 \\
Save irregularly & $-0.76^{* * *}$ & 0.16 & -0.10 & 0.08 \\
\hline Demographics and health status & & & & \\
\hline Female & $1.41^{* * *}$ & 0.33 & $1.08^{* * * *}$ & 0.11 \\
Log of age & $4.58^{* * *}$ & 0.62 & $0.55^{* * *}$ & 0.22 \\
De facto & -0.41 & 0.34 & 0.00 & 0.13 \\
Separated & $-4.48^{* * *}$ & 0.43 & $-1.34^{* * *}$ & 0.22 \\
Divorced & $-1.56^{* * *}$ & 0.42 & -0.12 & 0.16 \\
Widowed & $-2.28^{* * *}$ & 0.45 & $-0.69 * * *$ & 0.15 \\
Single never married & $-2.17^{* * *}$ & 0.50 & -0.13 & 0.19 \\
One dependent child & -0.27 & 0.24 & $-0.24 * * *$ & 0.10 \\
Two dependent children & -0.42 & 0.26 & -0.11 & 0.11 \\
Three dependent children & -0.039 & 0.35 & -0.04 & 0.16 \\
Long-term disability or illness & $-2.68^{* * *}$ & 0.16 & $-0.88^{* * *}$ & 0.06 \\
\hline Human capital & & & & \\
\hline Other post-secondary qualification & -0.073 & 0.38 & 0.09 & 0.14 \\
Secondary qualification & -0.54 & 0.38 & -0.17 & 0.14 \\
\hline
\end{tabular}




\begin{tabular}{|l|l|l|l|l|}
\hline Variable name $^{2}$ & \multicolumn{2}{|c|}{ Australia } & \multicolumn{2}{c|}{ UK } \\
\hline Employed part-time & 0.32 & 0.22 & 0.13 & 0.09 \\
Unemployed & $-2.87 * * *$ & 0.50 & $-1.09 * * *$ & 0.22 \\
Not in labour force & $-0.62 * * *$ & 0.23 & -0.10 & 0.10 \\
Underemployed & $-0.73 * *$ & 0.30 & -0.19 & 0.19 \\
\hline Community participation & & & & \\
\hline Volunteer & $0.42^{* * *}$ & 0.16 & $0.26 * * *$ & 0.06 \\
Active community group participation & $1.29 * * *$ & 0.15 & $0.20^{* * *}$ & 0.06 \\
\hline Constant & $57.69 * * *$ & 2.52 & $22.31 * * *$ & 0.86 \\
Number of observations & \multicolumn{2}{|c|}{45,600} & \multicolumn{2}{c|}{39,676} \\
R-sq & \multicolumn{2}{|c|}{0.078} & \multicolumn{2}{c}{045} \\
\hline
\end{tabular}

Source: See Table 1.

Notes: 1.The table contains RE regression estimates for wellbeing, on a scale 0-100 for Australia and 0-36 for the UK. 2. Where a continuous variable has a value of 0 , the $\log$ is set equal to 0 . Coefficients on the calendar year variables, omitted from this table for presentation purposes, are available from the authors upon request. Omitted categories are; Ongoing owners, Age under 35, Married, No dependent children, Tertiary qualifications, Employed full-time, Save regularly, and 2001. 3. Standard errors are in parentheses; * denotes coefficient statistically significant at $10 \%$; ** at $5 \%$; *** at $1 \%$, all for twotailed tests.

In a surprising twist, the model shows further (in the parameter estimates for the variables $L x$ post and $C x$ post $)$ that, following exit, and in both countries, the wellbeing of leavers (but not of churners) exhibits substantial recovery. For UK leavers, wellbeing levels rebound by just under two-thirds (relative to the wellbeing differential observed between ongoing owners and leavers prior to exit). In Australia the rebound amounts to just under one third of the prior-to-exit wellbeing differential $^{16}$. This suggests that whilst the prospect of leaving ownership may be stressful, having left can bring unanticipated benefits. However, the cross-country differences are striking, and there may be an institutional explanation for this.

In the UK, the wellbeing gain from exit may be related to the 'soft landing' offered by the social rented sector. Leaving owner-occupation is not sufficient to qualify; however, in the British public sector there is a long tradition of 'medical priority for rehousing' (Smith 1990). Although that sector has been radically restructured over

\footnotetext{
${ }^{16}$ Coefficients show that regardless of tenure the wellbeing levels of Australian leavers are 3.8 points lower than ongoing owners; but they rebound by 1.2 points (about one-third) following exit from ownership. In the UK, leavers' wellbeing is 0.9 points lower, but recover by 0.6 points (or nearly twothirds) following departure from ownership.
} 
time, and social housing allocation systems have changed (Smith and Mallinson 1997), on using the panel data to track housing pathways in the first decade of the $21^{\text {st }}$ century, we discover that fully $40 \%$ of UK leavers' post-exit person-years are spent in social housing, compared to $16 \%$ for churners. Moreover, those leavers who secured access to social renting experienced below average levels of wellbeing in almost half their pre-exit years. This may imply a 'selection effect' whereby some of those who exit with the lowest levels of wellbeing are preferentially admitted to social housing where they have the best chance of recovery (Smith et al. 1997).

Australian leavers report some rebound in wellbeing, but to a notably lesser extent than their British counterparts. The source of this recovery cannot be attributed to the benefits of social renting which is a minority option; Australian leavers spend just $5 \%$ of their post-exit person-years in that residual sector. For them, as for some of their UK counterparts, a number of life changes associated with exit might feature (for example the end of a stressful relationship), but the most likely additional explanation, with effects in both countries, is relief from the stress of unsustainable debt.

The tenure transitions model already indicates that the stressful circumstances of lasting leavers have an important financial dimension. On more detailed scrutiny we find that leavers could not meet (or had difficulty meeting) their mortgage payments in over $10 \%$ of pre-exit person-years in both countries. Ongoing owners rarely experienced such problems. Selling up relieves this stress, enabling Australian leavers to release a median $\$ 180,000$ ( $£ 70,000$ for UK leavers) - a game changing addition to spending power given median household incomes of $\$ 41,198$ and $£ 28,879$, 
respectively. For owners juggling pressing spending needs, and possibly uncertain employment prospects, the cash released on exit might, if only temporarily, account for some recovery of wellbeing.

The fact that churners experience no wellbeing rebound on exit may, in the case of the UK, at least, signal their greater likelihood (compared to lasting leavers) of relying on the private rented sector (perhaps because they do not have welfare needs that qualify them for social renting). In the UK, that sector lacks the choice, quality, condition and long-term security that might be needed to regain pre-exit levels of wellbeing, and being a market sector it is also less affordable (which can, as Mason et al. 2013 have indicated, be more stressful even than marginal ownership). Equally, churners in both countries may feel the pressure of having to find their way back into the more secure accommodation that, for them, owner-occupation represents. That motivation, and the stress that goes with it, could also reflect the foregone opportunities to accumulate housing equity that accompany lengthening spells in rental housing.

The unexpected finding that leavers' wellbeing levels rebound following exit is notable from a policy perspective. It is important, therefore, to test its robustness. To that end we report in Table 4, a fixed effects estimation of the tenure transition model. This is a helpful exercise because the FE estimator allows for correlation between $a_{i}$ and the explanatory variables included in the model defined by equation (1), a possibility that is ruled out by assumption in the RE model ${ }^{17}$. If such correlation were to be present the RE estimates would be biased and our key findings on the rebound

\footnotetext{
${ }^{17}$ Fixed effects redefines each variable as a deviation from the person specific mean. All included time invariant variables as well as $a_{i}$ drops out, and so we can safely ignore correlation between $a_{i}$ and the remaining explanatory variables as a source of bias. The Hausman test statistics for both countries are significant ( $1 \%$ level), indicating that the fixed effects model is preferred.
} 
in wellbeing could be spurious ${ }^{18}$. Though the FE model means that churner and leaver dummy variables are eliminated, we can still estimate the $L x$ post and $C \times$ post coefficients (key variables to detecting any rebound in wellbeing following exits from ownership) because these interaction variables are time varying.

Table 4 reports the fixed effect results; pooled OLS estimates are also reported as inferences can be drawn from comparison with the RE and FE findings. Checking these against table 3, it can be seen that the RE estimates are typically closer (than the pooled OLS estimates) to the FE estimates, though this is more evident in the Australian model. This is reassuring (Allison, p21, 2009), as is the finding that the FE estimator (being similar to the RE estimator) confirms the magnitude and statistical significance of the $L x$ post coefficient. Indeed, in the UK case, the rebound in wellbeing for leavers is slightly larger.

Table 4: Tenure transitions model, fixed effects and OLS ${ }^{1}$

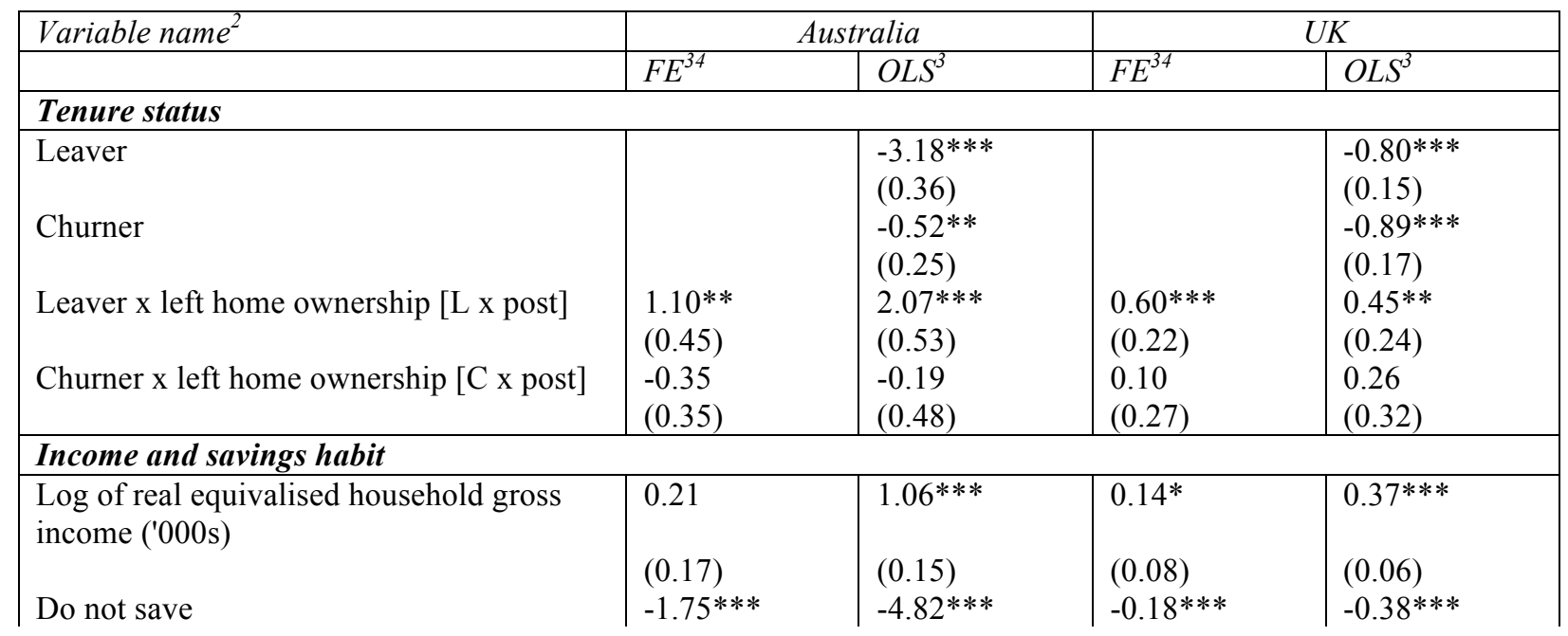

\footnotetext{
${ }^{18}$ For example, all leavers might happen to move into neighbourhoods that benefit from (unmeasured) neighbourhood renewal programmes that churners and ongoing owners' neighbourhoods do not benefit from. To the extent that neighbourhood renewal is responsible for lifting reported wellbeing levels, our finding that shifts into rental housing caused the rebound in wellbeing would be spurious.

Neighbourhood renewal is a fixed effect - whether or not a person lived in a neighbourhood benefiting from a renewal programme at some point in the study timeframe cannot vary from observation to observation. In the fixed effects model the correlation between such unmeasured time invariant variables and measured explanatory variable is purged and cannot therefore bias coefficient estimates.
} 


\begin{tabular}{|c|c|c|c|c|}
\hline \multirow[t]{2}{*}{ Variable name $^{2}$} & \multicolumn{2}{|c|}{ Australia } & \multicolumn{2}{|c|}{$U K$} \\
\hline & $F E^{34}$ & $O L S^{3}$ & $F E^{34}$ & $O L S^{3}$ \\
\hline Save irregularly & $\begin{array}{l}(0.22) \\
-0.63 * * * \\
(0.16)\end{array}$ & $\begin{array}{l}(0.22) \\
-1.10 * * * \\
(0.18)\end{array}$ & $\begin{array}{l}(0.06) \\
-0.08 \\
(0.09)\end{array}$ & $\begin{array}{l}(0.06) \\
-0.13 \\
(0.09)\end{array}$ \\
\hline \multicolumn{5}{|l|}{ Demographics and health status } \\
\hline $\begin{array}{l}\text { Female } \\
\text { Log of age }\end{array}$ & & $\begin{array}{l}1.48 * * * \\
(0.16) \\
6.12 * * * \\
(0.38)\end{array}$ & 0.00 & $\begin{array}{l}1.08 * * * \\
(0.06) \\
0.88 * * * \\
(0.14)\end{array}$ \\
\hline De facto & $\begin{array}{l}-0.39 \\
(0.39)\end{array}$ & $\begin{array}{l}0.057 \\
(0.28)\end{array}$ & $\begin{array}{l}-0.16 \\
(0.16)\end{array}$ & $\begin{array}{l}0.23 * * \\
(0.10)\end{array}$ \\
\hline Separated & $\begin{array}{l}-4.21 * * * \\
(0.46)\end{array}$ & $\begin{array}{l}-5.02 * * * \\
(0.44)\end{array}$ & $\begin{array}{l}-1.46^{* * *} \\
(0.24)\end{array}$ & $\begin{array}{l}-1.27 * * * \\
(0.21)\end{array}$ \\
\hline Divorced & $\begin{array}{l}-1.16^{* *} \\
(0.51)\end{array}$ & $\begin{array}{l}-1.59 * * * \\
(0.31)\end{array}$ & $\begin{array}{l}-0.10 \\
(0.22)\end{array}$ & $\begin{array}{l}-0.24 * * \\
(0.12)\end{array}$ \\
\hline Widowed & $\begin{array}{l}-4.07 * * * \\
(0.54)\end{array}$ & $\begin{array}{l}0.77 * * \\
(0.33)\end{array}$ & $\begin{array}{l}-1.60 * * * \\
(0.21)\end{array}$ & $\begin{array}{l}0.07 \\
(0.11)\end{array}$ \\
\hline Single never married & $\begin{array}{l}-1.67 * * \\
(0.69)\end{array}$ & $\begin{array}{l}-1.36 * * * \\
(0.34)\end{array}$ & $\begin{array}{l}-0.49 \\
(0.32)\end{array}$ & $\begin{array}{l}0.10 \\
(0.12)\end{array}$ \\
\hline One dependent child & $\begin{array}{l}-0.089 \\
(0.26)\end{array}$ & $\begin{array}{l}-0.97 * * * \\
(0.25)\end{array}$ & $\begin{array}{l}-0.21^{*} \\
(0.11)\end{array}$ & $\begin{array}{l}-0.33 * * * \\
(0.09)\end{array}$ \\
\hline Two dependent children & $\begin{array}{l}-0.35 \\
(0.30)\end{array}$ & $\begin{array}{l}-0.76^{* * * *} \\
(0.23)\end{array}$ & $\begin{array}{l}-0.11 \\
(0.13)\end{array}$ & $\begin{array}{l}-0.09 \\
(0.09)\end{array}$ \\
\hline Three dependent children & $\begin{array}{l}0.12 \\
(0.42)\end{array}$ & $\begin{array}{l}-0.47 \\
(0.29)\end{array}$ & $\begin{array}{l}-0.07 \\
(0.20)\end{array}$ & $\begin{array}{l}-0.06 \\
(0.13)\end{array}$ \\
\hline Long-term disability or illness & $\begin{array}{l}-1.67 * * * \\
(0.17)\end{array}$ & $\begin{array}{l}-7.23 * * * \\
(0.18)\end{array}$ & $\begin{array}{l}-0.49 * * * \\
(0.07)\end{array}$ & $\begin{array}{l}-1.66 * * * \\
(0.06)\end{array}$ \\
\hline \multicolumn{5}{|l|}{ Human capital } \\
\hline Other post-secondary qualification & $\begin{array}{l}0.19 \\
(0.90)\end{array}$ & $\begin{array}{l}0.52 * * * \\
(0.20)\end{array}$ & $\begin{array}{l}0.39 \\
(0.36)\end{array}$ & $\begin{array}{l}0.15^{*} \\
(0.08)\end{array}$ \\
\hline Secondary qualification & $\begin{array}{l}0.31 \\
(0.95)\end{array}$ & $\begin{array}{l}0.11 \\
(0.20)\end{array}$ & $\begin{array}{l}0.31 \\
(0.38)\end{array}$ & $\begin{array}{l}-0.10 \\
(0.08)\end{array}$ \\
\hline Employed part-time & $\begin{array}{l}0.40^{*} \\
(0.23)\end{array}$ & $\begin{array}{l}0.75 * * * \\
(0.23)\end{array}$ & $\begin{array}{l}0.10 \\
(0.11)\end{array}$ & $\begin{array}{l}0.27 * * * \\
(0.08)\end{array}$ \\
\hline Unemployed & $\begin{array}{l}-2.30 * * * \\
(0.50)\end{array}$ & $\begin{array}{l}-5.03 * * * \\
(0.66)\end{array}$ & $\begin{array}{l}-0.84 * * * \\
(0.23)\end{array}$ & $\begin{array}{l}-1.71 * * * \\
(0.25)\end{array}$ \\
\hline Not in labour force & $\begin{array}{l}-0.11 \\
(0.25)\end{array}$ & $\begin{array}{l}-1.61 * * * \\
(0.22)\end{array}$ & $\begin{array}{l}-0.06 \\
(0.12)\end{array}$ & $\begin{array}{l}-0.09 \\
(0.08)\end{array}$ \\
\hline Underemployed & $\begin{array}{l}-0.38 \\
(0.31)\end{array}$ & $\begin{array}{l}-2.64 * * * \\
(0.39)\end{array}$ & $\begin{array}{l}0.01 \\
(0.20)\end{array}$ & $\begin{array}{l}-0.74 * * * \\
(0.22)\end{array}$ \\
\hline \multicolumn{5}{|l|}{ Community participation } \\
\hline $\begin{array}{l}\text { Volunteer } \\
\text { Active community group participation }\end{array}$ & $\begin{array}{l}0.18 \\
(0.17) \\
0.76^{* * *} \\
(0.16) \\
\end{array}$ & $\begin{array}{l}1.21 * * * \\
(0.18) \\
2.86 * * * \\
(0.16)\end{array}$ & $\begin{array}{l}0.23 * * * \\
(0.07) \\
0.15 * * \\
(0.06)\end{array}$ & $\begin{array}{l}0.29 * * * \\
(0.06) \\
0.33 * * * \\
(0.05)\end{array}$ \\
\hline Constant & $\begin{array}{l}76.33 * * * \\
(1.01)\end{array}$ & $\begin{array}{l}50.68 * * * \\
(1.65)\end{array}$ & $\begin{array}{l}24.67 * * * \\
(0.43)\end{array}$ & $\begin{array}{l}21.10 * * * \\
(0.58)\end{array}$ \\
\hline $\begin{array}{l}\text { Number of observations } \\
\text { R-sq }\end{array}$ & $\begin{array}{l}45,600 \\
0.010\end{array}$ & $\begin{array}{l}45,600 \\
0.095\end{array}$ & & $\begin{array}{l}39,676 \\
0.051\end{array}$ \\
\hline
\end{tabular}

Source: Authors' calculations, 2001-10 HILDA and 2001-08 BHPS/US wave 2.

Notes: See notes 1, 2 and 3 from Table 3; 4. In the FE estimates age is removed because the inclusion of a full set of calendar year dummies means that we cannot estimate the effect of a variable whose change is constant across time. In this case it is age, which increases by one year from one wave to another, and its effect cannot therefore be distinguished from the aggregate time effects represented by year dummies (see Wooldridge, 2009, p484). 


\section{A financial transactions model}

Dropping out of ownership is a major biographical change that is often also associated with financial stress. A major source of financial stress around the edges of owneroccupation is debt, especially debt secured against the home. To explore the effects of this, we re-estimated both the random and fixed effects models (though only the former is presented in detail). To capture any 'mortgagor effect' on wellbeing we add a time-invariant binary variable equal to one if an individual was a mortgagor at any point during the timeframe, zero otherwise. We also added a measure of in situ equity borrowing, which we estimate separately for each ownership trajectory (ongoing owners, leavers and churners). The results of this financial transactions model are summarised in Table 5.

Table 5: Financial transactions model, random effects

\begin{tabular}{|c|c|c|c|c|}
\hline \multirow{2}{*}{ Variable name } & \multicolumn{2}{|c|}{ Australia } & \multicolumn{2}{|c|}{$\mathbf{U K}$} \\
\hline & Coefficient & SE & Coefficient & SE \\
\hline \multicolumn{5}{|l|}{ 'Mortgagor' effect } \\
\hline Mortgagor when a homeowner & $-1.15 * *$ & 0.49 & $-0.37 * *$ & 0.17 \\
\hline \multicolumn{5}{|l|}{ In situ equity borrowing and tenure status } \\
\hline Ongoing owner with equity borrowing & -0.34 & 0.47 & $-0.29 *$ & 0.15 \\
\hline Leaver with equity borrowing & $-5.53 * * *$ & 0.90 & $-1.30 * * *$ & 0.37 \\
\hline Leaver no equity borrowing & $-2.55 * * *$ & 0.89 & $-0.81 * *$ & 0.33 \\
\hline Churner with equity borrowing & -0.70 & 0.64 & $-1.04 * * *$ & 0.38 \\
\hline Churner no equity borrowing & $-1.61 * *$ & 0.63 & $-1.04 * * *$ & 0.33 \\
\hline $\begin{array}{l}\text { Leaver with equity borrowing x Left } \\
\text { home ownership }\end{array}$ & 0.63 & 0.61 & $0.64 * *$ & 0.32 \\
\hline $\begin{array}{l}\text { Leaver no equity borrowing x Left } \\
\text { home ownership }\end{array}$ & $1.53 * *$ & 0.62 & $0.52 *$ & 0.28 \\
\hline $\begin{array}{l}\text { Churner with equity borrowing x Left } \\
\text { home ownership }\end{array}$ & -0.13 & 0.59 & 0.45 & 0.53 \\
\hline $\begin{array}{l}\text { Churner no equity borrowing } x \text { Left } \\
\text { home ownership }\end{array}$ & -0.11 & 0.45 & 0.08 & 0.31 \\
\hline Observations & \multicolumn{2}{|c|}{45,600} & \multicolumn{2}{|c|}{39650} \\
\hline R-squared & \multicolumn{2}{|c|}{0.080} & \multicolumn{2}{|c|}{0.046} \\
\hline Number of xwaveid & \multicolumn{2}{|c|}{5,894} & \multicolumn{2}{|c|}{5,490} \\
\hline
\end{tabular}

Source: See Table 1.

Notes: see Table 3; additional omitted category: Ongoing owners who have not used in situ equity borrowing. Regression models also control for income and savings habit, demographics and health status, human capital, community participation and calendar years which are omitted from Table 5 for space reasons. Coefficient estimates on these additional controls largely confirm findings from earlier versions of the models. Complete results are available from the authors upon request. 
Table 5 shows that there is a substantial and significant mortgagor effect on wellbeing in both countries and both before and after the GFC (given inclusion of calendar year controls). This might be thought of as a debt effect, in that wellbeing is depressed for mortgagors relative to outright owners even after controlling for housing equity (through the inclusion of net imputed rent in the income variable), and effectively for house prices which some studies find important (Yilmazer et al. 2015). The model is therefore consistent with a literature that highlights the psycho-social risks of taking on secured debt. However, it is unusual for owner-occupiers to buy directly into outright home ownership in developed economies like Australia or the UK. Most require a mortgage first. If mortgagor status is the norm, it could be argued that the model taps into a wellbeing 'premium' associated with the transition to outright ownership.

In the $21^{\text {st }}$ century, there are many factors impeding the transition to outright ownership. The facility for equity borrowing is one of them. Instead of simply paying off their loan, households can borrow back, or even borrow up against rising prices. The model reported in Table 5 casts important light on the effects on wellbeing of equity borrowing even controlling for mortgagor status (as well as taking into account net housing wealth). For ongoing owners the effect is negative, though it is only statistically significant in the UK (at $10 \%$ ). So it may be that for mortgagors who are securely en route to outright ownership, any negative wellbeing effects of adding to debt are more or less offset by the wellbeing gains they receive from meeting spending needs without interrupting their overall trajectory. That is, the flexibility to use equity borrowing to bring forward consumption may offset the depressive effects 
of adding to debt.

In contrast, among leavers there is a marked wellbeing cost to equity borrowing. The difference in wellbeing between ongoing owners without equity borrowing and leavers who, as owners, had invoked that tactic is substantial and significant in both countries. It is the largest difference in either model for the Australian sample, and eclipsed only by the effect on wellbeing of relationship breakdown (separation) in the UK. Even among leavers themselves, equity borrowing (compared to those paying off their debts, or at least keeping them constant) depresses wellbeing. In Australia, this effect is substantial at $2.98(5.53-2.55)$ wellbeing points, and statistically significant (F-test, 1\% level). For UK leavers, the effect is in the same direction but less marked at 0.49 points $(1.299-0.810)$, and not statistically significant ${ }^{19}$. It is nevertheless reasonable to conclude that, among leavers, equity borrowing - a last resort in the face of pressing spending needs, and a preface to exit from ownership - detracts from wellbeing

There is less to say about churners, because the counts are small and the findings unreliable, especially for the UK. It seems that churners in both Australia and the UK have lower levels of wellbeing than ongoing owners of all kinds, regardless of financial tactics. But on exit, churners' wellbeing is substantially unchanged. The discovery that this is true regardless of churners' wealth management tactics while owners, ${ }^{20}$ is consistent with the fact that, in Australia, they are set apart from leavers because they carry substantial housing equity with them (Wood, Smith et al, 2013). It

\footnotetext{
${ }^{19}$ This latter finding may reflect the smaller sample numbers among UK leavers which, together with the narrower wellbeing scale, makes for stringent significance tests (much weaker effects from other variables show strong significance in the main sample, for example).

${ }^{20}$ These findings are confirmed by fixed effect estimates (available on request).
} 
may maintain, if not enhance, their wellbeing to know that they are well-positioned to regain ownership.

A final observation from Table 5 adds to our understanding of the wellbeing 'rebound' following transitions out of ownership reported earlier. In the UK, this rebound effect occurs irrespective of the fact or character of indebtedness. That is, there is a substantial, statistically significant, recovery of wellbeing for leavers, whether or not they were mortgagors and whether or not they engaged in equity borrowing. In Australia, in contrast, equity borrowers do not (while other leavers do) experience a rebound effect. This seems most likely to reflect the stress of debt overhang. Some reasons for this were proposed earlier. 


\section{CONCLUSION}

This paper contributes to a complex literature exploring the relationships between owner-occupation, health and wellbeing. Specifically, we document the effects of, first, tenure transitions out of ownership; and secondly, two financial transactions at the heart of modern housing markets (mortgage debt and equity borrowing).

In both countries, the tenure transitions model confirms that those on a trajectory out of ownership experience a level of stress, which - even controlling for common biographical disruptions and financial shocks - depresses wellbeing. An unexpected discovery, which we took extra steps to test, is that after leaving owner-occupation, the wellbeing of leavers (but not churners) shows partial rebound. This may partly reflect relief from financial stress. However, recovery is particularly notable in the UK where there may also be institutional effects stemming from the size and healthselectivity of the social rented sector.

Controlling for other relevant factors, churners' wellbeing on exit is less depressed (relative to ongoing owners) than that of lasting leavers. This is particularly notable in Australia where the private rental and informal housing sectors offer more flexibility than in the UK and 'churning' is more common (Wood et al. 2013). At the same time, however, churners exhibit lower wellbeing on exit than ongoing owners, and in contrast to lasting leavers, show no sign of recovery while renting. This group may be denied a soft landing in the social rented sector but are also, by definition, exposed to the financial challenge of regaining home ownership. 
The financial transactions model detects a positive 'outright ownership' effect in both countries; there is still a well-being premium attached to the ontological security that unmortgaged owner-occupation represents. Equally, however, the findings indicate that psycho-social stress is a key corollary of debt. This is supported by the observation that engaging in equity borrowing - a transaction designed to improve households' financial flexibility - independently depresses wellbeing, showing negative effects across all housing pathways. These effects are most substantial and significant among lasting leavers, where they exceed the effects, negative or positive, of nearly all other measurable predictors of wellbeing in the study.

If the test of a well-functioning housing system is the wellbeing of its occupants, the findings of this paper present a challenge for regimes anchored on owner-occupation. The edges of ownership are too broad, and the path to outright ownership too precarious, for home ownership to retain its reputation as a crucible of wellbeing. Institutional differences may inspire sustainable solutions within jurisdictions, but cross-national convergences dominate the findings, and they question the therapeutic qualities once ascribed to ownership-centred housing systems in the English-speaking world. 


\section{REFERENCES}

Allison, P. (2009) Fixed effects regression models Sage, Los Angeles.

Baker, E., Bentley, R. and Mason, K. (2013) The Mental Health Effects of Housing Tenure: Causal or Compositional?, Urban Studies, 50(2): 426-442.

Benito, A. (2007) Housing equity as a buffer: evidence from UK households, Bank of England WP324.

Bowles, S., Gintis, H. and Osborne, M. (2001) The Determinants of Earnings: A Behavioral Approach, J. Economic Literature (December) 39: 1137-76.

Bridges, S. and Disney, R. (2010) Debt and depression. J. Health Economics 29: 388403

Burgard, S. A., Seefeldt, K. S. and Zelner, S. (2012) Housing instability and health: findings from the Michigan recession and recovery study. Social Science and Medicine 75: 2215-2224.

Cairney, J. and Boyle, M. H. (2004) Home ownership, mortgages and psychological distress. Housing Studies 19:161-74.

Clapham, D. (2010) Happiness, wellbeing and housing policy. Policy and Politics 38: 253-267.

Dalstra, J. A. A., Kunst, A. E. and Mackenbach, J. P (2006) A comparative appraisal of the relationship of education, income and housing tenure with less than good health among the elderly in Europe. Social Science and Medicine 62: 2046-2060.

DEFRA (2005) Securing the Future: Delivering the UK Sustainable Development Strategy. London: TSO.

De Vogli, R. (2014) The financial crisis, health and health inequities in Europe. International Journal for Equity in Health 13: 58.

Downing, J. (2016) The health effects of the foreclosure crisis and inaffordable housing: a systematic review and explanation of evidence. Social Science and Medicine 162: 88-96

Easterlow D, Smith S J and Mallinson S (2000) Housing for health: the role of owner occupation Housing Studies 15 367-86.

Evans, J., Hyndman, S., Stewart-Brown, S., Smith, D., \& Petersen, S. (2000). An epidemiological study of the relative importance of damp housing in relation to adult health. J. Epidemiology and Community Health, 54, 677-686

Fichera, E. and Gathergood, J. (2013) House prices, home equity and health. York University: Health Economics Working Group WP 13/01 
Filakti, H. and Fox, J. (1995), Differences in mortality by housing tenure and by car access from the OPCS Longitudinal Study. Population Trends, 8: 27-30.

Goldberg DP, Gater R, Sartorius N, Ustun TB, Piccinelli M, Gureje O and Rutter C (1997) The validity of two versions of the GHQ in the WHO study of mental illness in general health care Psychological Medicine 27 191-197.

Karanikolos, M., Mladovskly, P., Cylus, J., Thomson, S., Basu, S., Stuckler, D., Mackenbach, J. P. and McKee, M. (2013) Financial crisis, austerity and health in Europe. The Lancet 381: 1323-31.

Keese, M. and Schmitz, H. (2014) Broke, ill, and obese: is there an effect of household debt on health? Review Income \& Wealth 60 (3) DOI10.1111/roiw.12002

Laurie, H. (2010) Continuity and innovation in the design of Understanding Society: the UK Household Longitudinal Study. Understanding Society Working Paper Series, ISER, University of Essex.

Lenton, P. and Mosley, P. (2008) Debt and Health. Working Paper. Department Economics, University of Sheffield ISSN 1749-8368

Lekkas, P., Paquet, C., Howard, N. and Daniel, M. (2016) Illuminating the lifecourse of place in the longitudinal study of place and health. Social Science and Medicine http://dx.doi.org/10.1016/j.socscimed.2016.09.025

Libman, K., Fields. D and Saegart, S (2012) Housing and health: a social ecological perspective on the United States foreclosure crisis. Housing, Theory and Society.

Lloyd, E., McCormack, C., McKeever, M., \& Syme, M. (2008). The effect of improving the thermal quality of cold housing on blood pressure and general health: a research note. J. Epidemiology and Community Health, 62, 793-797.

Macintyre S, Ellaway A, Der G, Ford G and Hunt K 1997 Do housing tenure and car access predict health because they are simply markers of income or self esteem? A Scottish study J. Epidemiology and Community Health 52 657-64.

Macintyre, S., Ellaway, A., Hiscock, R., Kearns, A., Der, G. and McKay, L. (2003) What features of the home and the area might help explain observed relationships between housing tenure and health? Evidence from the West of Scotland. Health and Place 9: 207-218.

McLaughlin, K. A., Nandi, A,, Keyes, K. M., Uddin, M., Aiello, A. E., Galea, S et al. (2011) Home foreclosure and risk of psychiatric morbidity during the recent financial crisis Psychological Medicine pp. 1-8

Mason, K. E., Baker, E., Blakely, T. and Bentley, R. J. (2013) Housing affordability and mental health: does the relationship differ for renters and home purchasers. Social Science and Medicine 94: 91-97.

Mueller, G. and Plug, E.S. (2006) Estimating the Effect of Personality on Male- 
Female Earnings, Industrial and Labor Relations Review 60(1), 3-22.

Nettleton, S. (1998) Losing homes through mortgage possession: a 'new' public health issue, Critical Public Health, 8, 53-63.

Nettleton, S. and Burrows, R. (1998), Mortgage Debt, Insecure Home Ownership and Health: An Exploratory Analysis. Sociology Health \& Illness, 20: 731-753.

Nettleton, S. and Burrows, R. (2000) When a capital investment becomes an emotional loss: thehealth consequences of the experience of mortgage possession in England, Housing Studies, 15, 463-79.

Nicholls, J. S., Ellaway, A. and MacIntyre, S. (1998) Does housing tenure predict health in the UK because it exposes people to different levels of housing-related hazards in the home or its environment? Health and Place 4 141-50.

Nyhus, E.K. and Pons, E. (2005) The effects of personality on earnings, Journal of Economic Psychology 26, 363-384.

Ong, R., Parkinson, S., Searle, B. A., Smith, S. J. and Wood, G. (2013) Channels from Housing Wealth to Consumption. Housing Studies 28: 1012-1036

Oswald, A.J and Powdthavee, N. (2008) Does happiness adapt? A longitudinal study of disability with implications for economists and judges, J. Public Economics 92: 1061-1077.

Pemberton, S. and Humphris, P. (2016) 'Locality, Neighbourhood and health: a literature review', IRiS Working Paper Series, No.13/2016 Birmingham: Institute for Research into Superdiversity

Parkinson, S, Searle, BA, Smith, SJ, Stoakes, A \& Wood, G (2009), 'Mortgage equity withdrawal in Australia and Britain: Towards a wealth-fare state?', European Journal of Housing Policy, vol.9, pp.363-87.

Pevalin, D. J. (2009). Housing repossessions, evictions and common mental illness in the UK: results from a household panel stud. J. Epidemiology \& Community Health, $63,949 \mathrm{e} 951$

Pevalin, D. J., Taylor, M. P. Todd, J. (2008), The dynamics of unhealthy housing in the UK: a panel data analysis, Housing Studies, 23:5, 679-695.

Rohe, W. M. and Lindbland, M. (2013) Re-examining the social benefits of homeownership after the Housing Crisis. Harvard: Joint Center for Housing Studies HBTL-04

Ross, L. M. and Squires, G. D. (2011). The personal costs of subprime lending and the foreclosure crisis: a matter of trust, insecurity, and institutional deception. Social Science Quarterly, 92, 140-163

Scanlon, K., Lunde, J., and C. Whitehead. 2008. Mortgage product innovation in 
advanced economies. European J. Housing Policy 8: 1-21.

Searle, B.A. (2008) Well-being: In Search of a Good Life? Bristol: Policy Press

Searle BA, Smith SJ and Cook N (2009) From Housing Wealth to Well-being?

Sociology Health and Illness, 31: 112-127.

Smith, S. J. (1990) Health Status and the Housing System. Social Science and Medicine 31: 753-762.

Smith, S. J. (2013) 'Crisis and Innovation in the Housing Economy: A Tale of Three Markets' in Financial Innovation - Too Much or Too Little? Cambridge, Mass: MIT Press (M. Haliossis, ed).

Smith, S. J. and Easterlow, D. (2005) The Strange Geography of Health Inequalities. Transactions, Institute of British Geographers 30: 173-190.

Smith, S. J. and Mallinson, S. (1997) Housing for Health in a Post-welfare State. Housing Studies 12: 173-200.

Smith, S. J. and Searle, B. A. (2008) Dematerialising money: the ebb and flow of wealth between housing and other things, Housing Studies 23(1), pp.21-43.

Smith, S. J., Alexander, A. and Easterlow (1997) Rehousing as a Health Intervention: Miracle or Mirage? Health and Place 5: 203-216.

Smith D. M., Langa K. M., Kabeto M. U., Ubel P. A., (2005) Health, wealth, and happiness: financial resources buffer subjective well-being after the onset of a disability. Psychological Science 16(9): 663-6.

Stuckler, D., Basu, S., Suhrcke, M. and McKee, M. (2009) The health implications of financial crisis: a review of the evidence. Ulster Medical Journal 78: 142-5.

Sweet, E/, Nandi, A., Adam. E. K. and McDade. T. W. (2013) The high price of debt: household financial debt and its impact on mental and physical health. Social Science and Medicine 91: 94-100

Ware JE, Snow KK, Kosinski M, Gandek B (1993) SF-36 Health Survey Manual and Interpretation Guide New England Medical Center, The Health Institute, Boston, MA.

Wood, G., Ong, R., and Cigdem, M. (2012) 'Factors Shaping the Dynamics of Housing Affordability in Australia', Final Report, No. 244. Melbourne: Australian Housing and Urban Research Institute.

Wood, G., Parkinson, S., Ong, R., Searle, B. A. and Smith, S. J. (2013) 'Motivations for Equity Borrowing: A Welfare Switching Effect', Urban Studies, 50(12), 25882607.

Wood, G., Smith, S. J., Ong, R. and Cigdem, M. (2013) The Edges of Home 
Wood, G., Smith, S. J., Cigdem, M. and Ong, R. (2015) Life on the edge: a perspective on precarious home ownership in Australia and the UK. International Journal of Housing Policy DOI: 10.1080/14616718.2015.1115225

Wooldridge, J. M. (2009), Introductory Econometrics; A Modern Approach. $4^{\text {th }}$ Edition, South Western Centre Learning, Mason.

Yilmazer, T., Babiarz, P., and Liu, F. (2015) The impact of diminished housing wealth on health in the United States: Evidence from the Great Recession. Social Science and Medicine 130: 234-241

Zumbro, T. (2014), The relationship between homeownership and life satisfaction in Germany, Housing Studies, 29:3, 319-338. 